\title{
Three Futures Scenarios of Policy Instruments for Sustainable Textile Production and Consumption as Portrayed in the Finnish News Media
}

\author{
Laura Virta and Riikka Räisänen * \\ Craft Studies, Faculty of Education, University of Helsinki, FI-00014 Helsinki, Finland; lauravirta@iki.fi \\ * Correspondence: Riikka.raisanen@helsinki.fi; Tel.: +358-503183973
}

Citation: Virta, L.; Räisänen, R.

Three Futures Scenarios of Policy

Instruments for Sustainable Textile Production and Consumption as Portrayed in the Finnish News Media. Sustainability 2021, 13, 594.

https://doi.org/10.3390/su13020594

Received: 1 December 2020

Accepted: 7 January 2021

Published: 9 January 2021

Publisher's Note: MDPI stays neutral with regard to jurisdictional clai$\mathrm{ms}$ in published maps and institutional affiliations.

Copyright: $\odot 2021$ by the authors. Licensee MDPI, Basel, Switzerland. This article is an open access article distributed under the terms and conditions of the Creative Commons Attribution (CC BY) license (https:// creativecommons.org/licenses/by/ $4.0 /)$.

\begin{abstract}
This research uses futures studies as background methodology and presents three scenarios for sustainable textile production and consumption based on the data of the Finnish news media. The scenarios extend to 2050, and the emphasis is on recognising policy instruments that can potentially support sustainable textile production and consumption. The first data set included 214 news articles from 2019 that were analysed using theory-guided qualitative content analysis. The second data set consisted of five textile experts' evaluations of the probability and preferability of claims based on the first data set. As a result, a table of futures scenarios was created, including descriptions of the current state and preferable, threatening and probable textile futures. The data show that textile and fashion sustainability issues are strongly presented in the media as part of the comprehensive climate-changedriven criticism of consumerism. The data emphasised a need for a holistic change in production and consumption. The most likely forms of policy instruments appear to be stronger corporate responsibility legislation (regulatory), environmental taxation of goods and services (economic), and eco-labelling of goods and services (information). These help in reaching the preferable scenario for 2050, which suggests a carbon-neutral textile production based on a circular economy.
\end{abstract}

Keywords: textile production; futures studies; environmental taxation; carbon neutrality; circular economy; holistic change

\section{Introduction}

The textile industry has a significant role in the world whether we look at production volume, sales or environmental impact [1,2]. At the same time, everyone is a consumer of textiles, which makes the issue relevant and important at all levels. Our current textile production and consumption practices are widely recognised as ethically and ecologically unsustainable. Despite being an industry with such wide impacts, the efforts to turn around this unsustainable course seem to rely relatively strongly on the efforts of single organisations, consumers or producers. Therefore, this study focused on finding signs of stronger political, economic and comparable actions that might strengthen these pro-environmental and sustainability efforts and help target the industry's problems systematically and thoroughly. Such studies on the use of policy instruments in the textile context appear to be scarce, and the topic calls for a closer examination. The driving objective of this study was to find out if there is more, or something different, we (i.e., researchers, authorities, policy makers) could do with the right directing methods to support the manufacturing of longlasting, high-quality, low-impact and humanely produced textiles, and their discretionary and responsible use. Consuming is known to be a complex socio-psychological mechanism, where rational and consistent choices do not often take place, and where attitudes and behaviour do not always line up; see, e.g., [3,4]. Trusting the consumer, then, to make responsible textile purchases without any or conflicting guidelines has varying outcomes. Additionally, the intertwining relationship between production and consumption requires both to be viewed and improved together $[3,5]$. 
The textile sector is by nature a future-oriented industry in which the aim is to create a timely foresight of styles, trends and consumer behaviour [6]. It is also an industry in which technological innovations are rapidly transforming the ways in which fibres and garments are made and used. Therefore, a futures studies approach was chosen to paint a picture of the possible turns the industry may take, depending on the policy instruments that are available and their effectiveness. Futures studies as background methodology in textile production and consumption research is rare, which highlights the novelty of this article.

Firstly, the focus was on finding and recognising policy instruments that may play a role in shaping textile futures. Secondly, the evolution of textiles and their production and consumption practices were examined to create an overall understanding of the industry and the environment the policy instruments operate in.

The two main research questions were:

1. What forms, options and restrictions can be found in the news for policy instruments supporting sustainable textile production and consumption?

2. What images of the future of textile production and consumption are portrayed in the news?

\subsection{Sustainable Production and Consumption}

Much has been written about the social and environmental impacts that the textile industry has on textile workers, users and natural resources. Material dependency, raw material production, long and geographically-scattered production chains, as well as colourings, finishings and other chemicals used during the manufacturing processes make the environmental load of textiles a heavy one, and poor working conditions and the use of child labour are examples of the industry's social faults, e.g., [1,7]. The defining features of the current textile production and consumption are volume and speed, as clothing production and purchases have doubled over the last twenty years, while at the same time the use of each piece of clothing before it is discarded has decreased by more than one-third [1,8]. A vicious circle of inexpensive, low-quality production and a short lifespan of usage prevails. To break the circle, changes are called for in all stages of the production and consumption chain, as the problem lies in the whole figure $[9,10]$.

Carbon neutrality has increasingly been emphasised in the recent discussions about sustainability. While carbon emissions are not the textile industry's only challenge for sustainability, they are fundamental for climate change. The textile industry has been estimated to produce $8-10 \%$ of the world's carbon emissions, excluding the considerable retail and use phase emissions from transportation and laundering [1,11,12]. Carbon neutrality has been announced as an aim for the Finnish textile industry [13], as part of the nationwide goal for Finland to become carbon neutral by 2035 [14,15]. In simple terms, carbon neutrality refers to balancing the emissions and absorption of carbon dioxide $\left(\mathrm{CO}_{2}\right)$ so that the quantity of emissions produced is not higher than the one that is simultaneously absorbed in carbon sinks, i.e., any system that absorbs more carbon than it emits, such as forests, soil and oceans [16]. In equally simple terms, this can be achieved either by reducing the carbon emissions of any target action, or by adding capacity to the world's carbon sinks, or a combination of both. Yet, for complex systems such as the textile industry, carbon neutrality is not a simple aim. Because the production chains from raw material manufacturing to the end user extend across the globe and nations, it is not easy to define the "Finnish textile industry", its emissions or the sinks needed for compensation. From the climate perspective, the world's total carbon emissions are crucial, and therefore simply shifting emissions geographically or from one sector to another does not help. Without clear definitions, calculations and monitoring, carbon neutrality is just rhetoric.

Carbon neutrality endeavours are based on carbon footprint calculations that sum up the total greenhouse gas emissions (mainly $\mathrm{CO}_{2}$ and methane) of any defined action, area, event, group or product $[17,18]$. International standards give guidelines for carbon footprint calculations, and the ISO 14,060 family of standards is used for quantifying, 
monitoring, reporting and validating greenhouse gas emissions to support a low-carbon economy [18]. However, the calculations are very complex and are always estimates: they take into account selected aspects leaving others unheeded. Nevertheless, standards will provide a better understanding of ways in which complex systems can be directed to reduce emissions and increase sustainability.

Carbon neutrality is intertwined with the circular economy, and a carbon-neutral circular economy is often referred to as the ultimate sustainability goal. The circular economy relies on principles that minimise waste and pollution and allow materials to stay in use; instead of a linear system, in which resources enter and waste is the final output, the circular economy forms a closed loop [10]. The Ellen MacArthur Foundation [8] (pp. 22-25) has defined four steps for reaching a circular textile economy:

(1) eliminate harmful substances and microfibre release,

(2) break the disposable nature of clothes by transforming the ways they are designed, sold and used,

(3) improve recycling, and

(4) use resources effectively and move to renewable inputs.

\subsection{Policy Instruments as Tools to Direct Production and Consumption}

Our daily choices and actions are guided, limited and persuaded by an assortment of policy instruments. These refer to the set of techniques that governments possess to support or prevent social change [19]. When producing or consuming goods or services, policy instruments directly or indirectly affect, for example, their availability, prices, quality and safety. Thus, when it comes to sustainable textile production and consumption, policy instruments have the potential to help navigate the way.

Policy instrument tools can be classified in several ways. The simplest categorisation is to see them either as positive or negative, either promoting or restraining an action. Commonly used is their threefold classification into regulations, economic means and information. Regulations refer typically to obligatory rules, legislation being its well-known form. A sanction often follows from breaking these rules. Economic policy instruments base their impact on the trade of money, time or other resources. Depending on the aim, an action or a purchase is made easier or more difficult, faster or slower, cheaper or more expensive. Taxation is often considered to be the most common economic policy instrument. The information category includes a variety of attempts to influence people by providing knowledge, reasoned arguments and persuasion. This may include anything from education to advertising, labelling, brochures and campaigns [19].

Textiles are controlled by several laws, most of which aim for the safety and health of textiles users. As with most consumer goods, legal rules also affect the ways in which textiles are manufactured, sold and marketed. Once a textile is considered waste, it is treated under the Waste Act. Fletcher [9] (p. 54) claims that regulatory directing had a more prominent role in shaping textiles' sustainability in the past. The 1990s saw media reports on poor working conditions at textile factories followed by consumer boycotts, which led in part to legally binding improvements at the manufacturing stage, and the ban on carcinogenic azo dyes, for example. Since then, the bare minimum required by law has not been enough for producers and consumers with more ambitious sustainability endeavours, and brands' and companies' own sustainability programmes and practices are playing a bigger role in shaping the industry's standards. A study by Seppälä et al. [20] (pp. 38, 41) mapped ways to support the circular economy in Finland and saw potential in a so-called eco-design directive. The directive could set the minimum requirements for the durability and recyclability of products to take into account as early on as in the design phase. Another promising regulatory directing method recognised in the study was producer responsibility, which, if applied, was expected to have far-reaching effects on the choice of the quality and quantity of materials and the life span of products.

Some forms of economic directing that affect textile manufacturing and trade in Finland include the value added tax (highest tax group of $24 \%$ applies on textiles and textile 
services, such as repairs and garment renting) and customs duty (12\% on most common textile products but varies depending on the textile category, material and country of origin) [21,22]. The Finnish Committee on Sustainable Consumption and Production has suggested several economic implementations for directing production and consumption towards sustainability, many of which could also be applied to textile products. Consumerrelated suggestions include a lower value added tax on repair services and environmentally friendly products and services; extending tax credit for household expenses to repair services; and making income from share-use tax-free up to a limit. Suggestions for producers include emission and natural resource quotas for different industries, and allocating taxes according to emissions and environmental impacts [23] (pp. 32, 34). A successful, though not textile-related, example of economic direction is the Finnish bottle deposit system, which has helped to raise the recycling rate of bottles and cans to over $90 \%$ [24].

The care tags attached to garments can be considered textile-related information direction in one of its simplest forms. Some product categories have a score showing how the item performs on a specific attribute, such as the energy efficiency classification required on electronic devices. The most extensive eco-labels and standards usually take into account several aspects of sustainability, and in doing so require the producer to thoroughly assess the processes from manufacturing to end use. Compared to groceries, cosmetics and household products, eco-labels are more rarely found on textiles. Some reasons for this have been found to lay in the lack of knowledge of different certificates and their potential benefits, as well as the time, effort and money required by the certification process [25]. So-called negative labels are another way of informing the consumer, such as the warning signs found on cigarette packs. A study suggested that consumers may respond more strongly to negative than to positive labels, a result that is interesting when choosing the most impactful approach with information direction [26]. While the information placed on the product itself is one way of informing the consumer, another, underused one, is to communicate the quality and longevity of a product by offering guarantees.

Choosing the right set of policy instruments to promote or restrict any action and using it consistently is essential. If policy instruments contradict one another, fluctuate or are hard to foresee or follow, producers could be discouraged from innovating or investing $[10,27]$. Policy instruments have the greatest impact when they simultaneously weaken the current unsustainable conventions and support new sustainable actions $[5,28]$. Consumers' readiness for stronger political control is commonly concluded from surveys. In a recent survey, as many as $65 \%$ of the Finnish respondents evaluated their own opportunities to influence the environmental crisis as being low or non-existent [29]. This consumer sense of powerlessness can be decreased by wise and timely policy instruments, which function as guidelines, directives and instructions. Legislation, politics, global market, technologies and other social phenomena are human-made and human-operated systems, which only function and have an impact through human actors, not on their own. Therefore, we also have the power to change them to better serve our needs [30,31].

\subsection{Futures Studies and Deeds}

Futures studies are concerned with what is possible, what is probable, what is preferable and what is avoidable. The discipline is also actively participating in creating and shaping the preferred futures, e.g., [32]. A research subject that does not yet exist at the time of research poses indisputable challenges, but signs in the past and present can give out clues of the future. Four types of future signs are often described. Megatrends are strong, widely spread and expected to continue at least for several years or decades (climate change, population growth, etc.). Trends are typically smaller in scale and shorter in duration but still clearly recognisable (e.g., fashion or nutrition trends). Weak signals are less obvious, often considered to be unusual at first sight, but carry the potential for a change, which may or may not grow to become a larger trend (e.g., forerunners, prototypes, experiments and other pilot projects). Black swans or wild cards refer to at least somewhat 
unexpected and unpredicted events that can have a major impact (such as accidents or epidemics) $[33,34]$.

Despite being on the lookout for future signs, we are not the future's passive bystanders. The future is not predestined or inevitable, but constantly formed through our actions and decisions. Future scenarios or images of the future are typically created in futures studies. They help understand the possible outcomes which different actions may have and function as tools for planning, foresight and decision making. Technically, scenarios are chains of events with a range of consequences, while images of the future can be thought of as still shots of any given time. The way we visualise the future is not irrelevant; instead, it can substantially affect the way the future unfolds, because our images of the future have a tendency to influence our actions in the present. Uncertain, intimidating or hopeful images make us act in different ways [35]. The relationship is two-way: we shape the future, and our images of the future shape us.

\section{Material and Methods}

The research questions expressed in Chapter 1 were approached with two sets of data. First, news articles were collected from two major Finnish news media sources, Yle Uutiset (Yle News) and Helsingin Sanomat, which collectively reach the majority of Finns through their print, online and TV news. Yle News is a nationwide, government-owned media outlet, and Helsingin Sanomat is the biggest newspaper in Finland, based in the Helsinki capital region, and part of Sanoma Media Finland media company (for Yle's operating principles, see [36], and for Sanoma Media Finland's corporate responsibility, see [37]). Both are members of the Council for Mass Media, which agrees to support good journalistic practice and responsible freedom of speech [38].

News data are an interesting window to monitor what is going on in the textile sector from the viewpoint of both producers and consumers. Using the online news archives, the search was limited to the first six months of 2019. The search words textile, consumption, production, policy instrument, future and environment led to 214 news articles being gathered for the study after excluding irrelevant hits, such as news that contained a keyword but did not discuss textile production and consumption issues or the use of policy instruments generally. Theory-guided qualitative content analysis was then applied to analyse the news data, using the ATLAS.ti 8 software (ATLAS.ti Scientific Software Development $\mathrm{GmbH}$, Corvallis, OR, USA) to organise, code and group the data. To answer the first research question, the analysis was guided by the three groups of policy instruments discussed earlier in Section 1.2, i.e., regulation, economic tools and information media. A fourth group, consumer influence, was created inductively from the data, as consumers were often portrayed as active drivers of change, not only as objects of political direction. For the second research question, the data were organised loosely according to the frame of sustainable production and consumption, as portrayed in the United Nations 2030 Agenda for Sustainable Development goals. Goal 12, Sustainable Consumption and Production, includes objectives such as the sustainable use of natural resources, environmentally sound management of chemicals, waste reduction and sustainable production technologies [39].

To evaluate the meaning and significance of the first data findings and to support the research questions further, a second data set was collected from a group of experts $(n=5)$ in the form of a questionnaire. To form this small panel, nine researchers and other experts on textile-related issues were approached by email, seven of whom agreed to participate and were sent a link to the questionnaire, and finally five completed the questionnaire. Each of the five respondents had expertise in one or several of the following fields: sustainable textile materials, eco-labelling and textile sector's social responsibility. The nine original contacts were chosen based on their academic and professional contributions to the issues related to this study. Their expertise was regarded as a valuable addition to the data, but was not expected to provide a comprehensive or solid response to the complex issues, or to represent the many actors in the textile sector. Using expert panels has a long history and strong methodological basis in futures studies, as forming plausible futures' scenarios on 
any topic is challenging, if not impossible, for a single researcher. The use of a panel, even if a small one, was an acknowledgement of this. Instead of an agreement and consensus among a big panel, contemporary futures studies panels often pursue perceptions and arguments and are smaller in number [40].

For the questionnaire, statements regarding textile futures and the impact of policy instruments were formed based on the first set of data (news). The experts evaluated the probability and preferability of each statement on a scale from one to four, where one signified not probable/not preferable and four signified probable/preferable. Space for written comments and arguments was also provided next to each statement. Using the results of the first data set (news) and the second data set (experts' evaluations), a table of futures scenarios was created (Table 1). Focusing on the policy instruments and their possible impacts, three scenarios for textile futures were presented as

- preferable,

- threatening (non-preferable) and

- probable futures.

Table 1. Three futures scenarios and the current status of policy instruments for sustainable textile production and consumption in Finland.

\begin{tabular}{|c|c|c|c|c|}
\hline Policy Instrument & $\begin{array}{c}\text { Current State: } \\
\text { Time Capsule on the } \\
\text { Verge of } 2020\end{array}$ & $\begin{array}{l}\text { Preferable Future: } \\
\text { Ecological } \\
\text { Reconstruction }\end{array}$ & $\begin{array}{l}\text { Threatening Future: } \\
\text { Locked-in Systems }\end{array}$ & $\begin{array}{l}\text { Probable Future: } \\
\text { Circular Economy }\end{array}$ \\
\hline \multicolumn{5}{|c|}{ Research Question 1: Policy Instruments for Sustainable Textile Production and Consumption } \\
\hline \multirow{3}{*}{ Regulatory } & $\begin{array}{l}\text { Inconsistent political } \\
\text { direction }\end{array}$ & $\begin{array}{l}\text { Strong and consistent } \\
\text { political direction }\end{array}$ & $\begin{array}{l}\text { Political direction } \\
\text { inconsistent and } \\
\text { inadequate }\end{array}$ & $\begin{array}{l}\text { Political direction } \\
\text { strengthening and } \\
\text { more consistent }\end{array}$ \\
\hline & $\begin{array}{l}\text { Legislation emphasis } \\
\text { on consumer safety }\end{array}$ & $\begin{array}{l}\text { Corporate } \\
\text { responsibility required } \\
\text { by law }\end{array}$ & OR & $\begin{array}{l}\text { Corporate } \\
\text { responsibility required } \\
\text { by law }\end{array}$ \\
\hline & $\begin{array}{l}\text { EU-wide textile waste } \\
\text { separation and } \\
\text { recycling requirement } \\
\text { expected in } 2025\end{array}$ & $\begin{array}{l}\text { Demand for } \\
\text { responsibility in public } \\
\text { procurement law }\end{array}$ & $\begin{array}{l}\text { Extreme sanctions and } \\
\text { restrictions }\end{array}$ & $\begin{array}{l}\text { Demand for } \\
\text { responsibility in public } \\
\text { procurement law }\end{array}$ \\
\hline \multirow{4}{*}{ Economic } & $\begin{array}{l}\text { Value added tax on } \\
\text { textiles and textile } \\
\text { services } 24 \%\end{array}$ & Ecological tax reform & $\begin{array}{l}\text { Impact of taxation on } \\
\text { consumption } \\
\text { ineffective }\end{array}$ & $\begin{array}{l}\text { Environmental tax on } \\
\text { products and services }\end{array}$ \\
\hline & $\begin{array}{l}\text { Emission } \\
\text { compensations on } \\
\text { some purchases }\end{array}$ & $\begin{array}{l}\text { Environmental tax on } \\
\text { products and services }\end{array}$ & $\begin{array}{l}\text { Personal emission or } \\
\text { consumption quotas }\end{array}$ & Value added tax reform \\
\hline & $\begin{array}{l}\text { Discussions on, e.g., } \\
\text { environmental taxes } \\
\text { and ecological } \\
\text { tax reform }\end{array}$ & $\begin{array}{l}\text { Tax relief on } \\
\text { textile services }\end{array}$ & & $\begin{array}{l}\text { Emission } \\
\text { compensations } \\
\text { on purchases }\end{array}$ \\
\hline & & $\begin{array}{l}\text { Corporate subsidies } \\
\text { based on } \\
\text { environmental impact }\end{array}$ & & $\begin{array}{c}\text { Corporate subsidies } \\
\text { based on } \\
\text { environmental impact }\end{array}$ \\
\hline \multirow{2}{*}{ Information } & $\begin{array}{c}\text { Eco-labels and } \\
\text { standards on textiles } \\
\text { relatively few }\end{array}$ & $\begin{array}{l}\text { Eco-labels } \\
\text { and standards }\end{array}$ & $\begin{array}{l}\text { Complex mix of } \\
\text { eco-labels and } \\
\text { standards }\end{array}$ & $\begin{array}{c}\text { Eco-labels and } \\
\text { standards on textiles } \\
\text { more common }\end{array}$ \\
\hline & & $\begin{array}{l}\text { Textile warranties and } \\
\text { repair and } \\
\text { maintenance services }\end{array}$ & $\begin{array}{l}\text { Voluntary direction } \\
\text { methods ineffective }\end{array}$ & \\
\hline \multirow[t]{2}{*}{ Consumer influence } & $\begin{array}{l}\text { Growing demand } \\
\text { for sustainability }\end{array}$ & $\begin{array}{l}\text { Sustainable } \\
\text { consumption as } \\
\text { a megatrend }\end{array}$ & $\begin{array}{l}\text { Tightening political } \\
\text { control causes } \\
\text { resistance } \\
\text { among consumers }\end{array}$ & $\begin{array}{l}\text { Sustainable } \\
\text { consumption as } \\
\text { a megatrend }\end{array}$ \\
\hline & Shopping strikes & & $\begin{array}{c}\text { Sustainable } \\
\text { consumption not a } \\
\text { prevailing trend }\end{array}$ & \\
\hline
\end{tabular}


Table 1. Cont.

\begin{tabular}{|c|c|c|c|c|}
\hline Policy Instrument & $\begin{array}{l}\text { Current State: } \\
\text { Time Capsule on the } \\
\text { Verge of } 2020\end{array}$ & $\begin{array}{l}\text { Preferable Future: } \\
\text { Ecological } \\
\text { Reconstruction }\end{array}$ & $\begin{array}{l}\text { Threatening Future: } \\
\text { Locked-in Systems }\end{array}$ & $\begin{array}{l}\text { Probable Future: } \\
\text { Circular Economy }\end{array}$ \\
\hline \multicolumn{5}{|c|}{ Research Question 2: Future Outlooks on Sustainable Textile Production and Consumption } \\
\hline \multirow{6}{*}{ Production } & $\begin{array}{l}\text { Textile industry } \\
\text { responsible for ca. } 2.5 \% \\
\text { of world emissions }\end{array}$ & Carbon neutrality & $\begin{array}{l}\text { Textile industry } \\
\text { responsible for } 25 \% \text { of } \\
\text { world emissions }\end{array}$ & Carbon neutrality \\
\hline & $\begin{array}{l}\text { Polyester ca. } 70 \% \text { and } \\
\text { cotton } 25 \% \text { of textile } \\
\text { fibres }\end{array}$ & Circular economy & $\begin{array}{l}\text { Growing wood pulp } \\
\text { production threatens } \\
\text { forest renewal }\end{array}$ & Circular economy \\
\hline & $\begin{array}{c}\text { Developing new } \\
\text { sustainable materials }\end{array}$ & $\begin{array}{l}\text { Sustainably produced } \\
\text { and diverse } \\
\text { textile materials }\end{array}$ & $\begin{array}{l}\text { Production shifts to } \\
\text { locations with looser } \\
\text { emission restrictions }\end{array}$ & $\begin{array}{l}\text { Sustainably produced } \\
\text { and diverse } \\
\text { textile materials }\end{array}$ \\
\hline & $\begin{array}{l}\text { Developing recycling, } \\
\text { repair and shared } \\
\text { use services }\end{array}$ & $\begin{array}{l}\text { Small scale and } \\
\text { craft-like production }\end{array}$ & & $\begin{array}{l}\text { Sustainable } \\
\text { mass production }\end{array}$ \\
\hline & & Local textile production & & New business models \\
\hline & & Emphasis on quality & & $\begin{array}{l}\text { Mass production } \\
\text { in Africa }\end{array}$ \\
\hline \multirow{5}{*}{ Consumption } & $\begin{array}{l}\text { Second-hand and } \\
\text { shared use } \\
\text { clothing growing }\end{array}$ & $\begin{array}{l}\text { Textiles purchases } \\
\text { emphasise quality }\end{array}$ & $\begin{array}{l}\text { Growing number of } \\
\text { textile purchases and } \\
\text { fewer use times per } \\
\text { clothing item }\end{array}$ & $\begin{array}{l}\text { Water and energy } \\
\text { consumption in textile } \\
\text { use-phase decreases }\end{array}$ \\
\hline & $\begin{array}{l}\text { Low garment } \\
\text { usage rate }\end{array}$ & $\begin{array}{c}\text { High garment } \\
\text { usage rate }\end{array}$ & $\begin{array}{c}\text { Price primary deciding } \\
\text { factor on the expense of } \\
\text { quality } \\
\text { and sustainability }\end{array}$ & $\begin{array}{l}\text { Alternative modes of } \\
\text { consumption } \\
\text { and ownership }\end{array}$ \\
\hline & $\begin{array}{l}\text { Clothes } \\
\text { purchased rising }\end{array}$ & $\begin{array}{l}\text { Shared use and other } \\
\text { alternative modes of } \\
\text { textile consumption }\end{array}$ & & $\begin{array}{l}\text { Textile waste } \\
\text { decreasing as } \\
\text { recycling improves }\end{array}$ \\
\hline & $\begin{array}{l}\text { Textile waste ca. } 17 \\
\text { kg/person/year } \\
\text { in Finland }\end{array}$ & $\begin{array}{l}\text { Water and energy } \\
\text { consumption in } \\
\text { use-phase decreases }\end{array}$ & & \\
\hline & $\begin{array}{l}\text { Clothes with respect to } \\
\text { income cheaper } \\
\text { than ever }\end{array}$ & $\begin{array}{c}\text { Era of } \\
\text { post-consumerism }\end{array}$ & & \\
\hline
\end{tabular}

The fourth column in Table 1 describes the state of textile production and consumption sustainability issues and related policy instruments in 2019 in Finland as presented in the news data.

Figure 1, modified in line with Voros's (2017) Futures Cone [41], helps to illustrate these different types of futures and their relationships. Everything beyond the present moment is a potential future. Preposterous futures refer to the "impossible" futures that we expect never to happen. Possible futures are futures that "might" happen if we gain some knowledge or skills we do not yet have. Plausible futures "could" happen, based on our current knowledge of the world. Threatening, preferable and probable futures are further discussed in this study. Preferable (and non-preferable, here described as threatening) futures are based on value judgements, what we "want" or do not want to happen. Probable futures are considered "likely" to happen. The placing of threatening, preferable and probable futures on the cone suggests that some aspects of the threats or preferences are likely to happen, some could happen and some probably never will. 


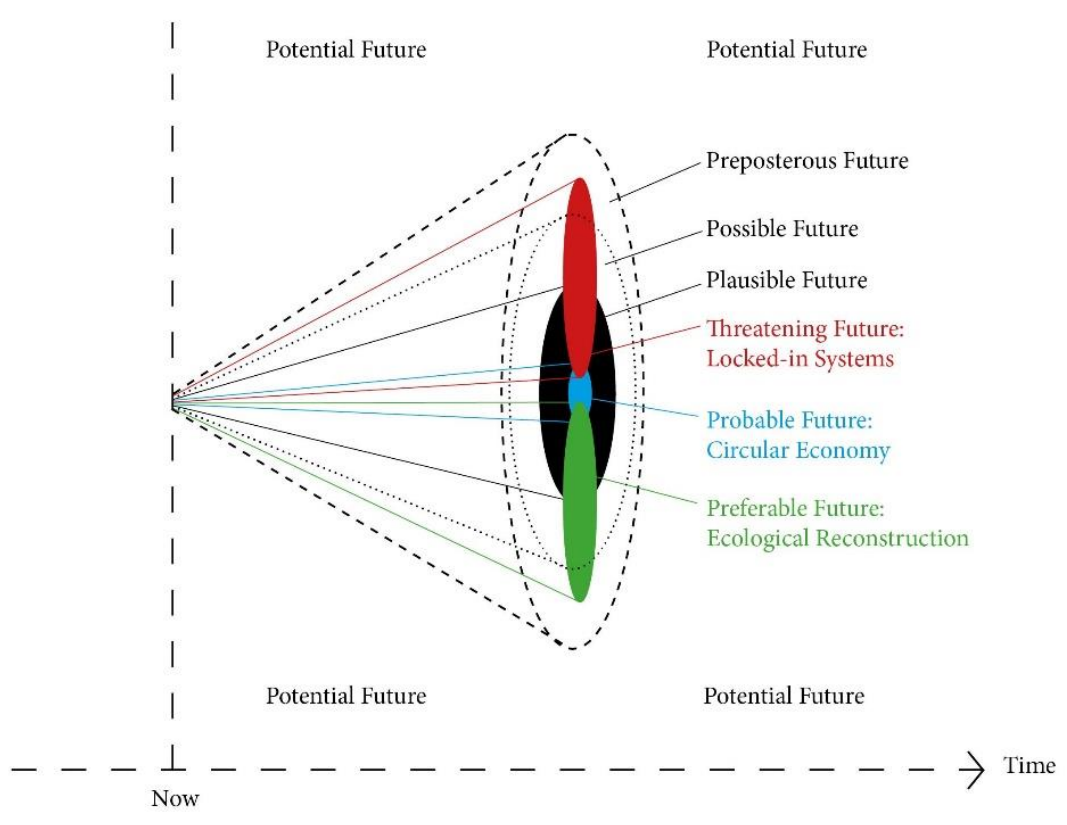

Figure 1. Futures Cone modified after Voros (2017).

\section{Results and Discussion}

The sustainability issues concerning the textile and fashion industry have been widely presented in the Finnish news media recently. This is in line with the environmental and climate crisis that is forcing us to rethink our daily practices comprehensively. Policy instruments directed at sustainable production and consumption have also been discussed in the media, especially in the context of transportation, energy sources and nutrition, but less in the context of textiles. In this study, the first research question aimed at finding policy instruments and their implementations-present and future-from the viewpoint of textiles. The second research question searched for general future outlooks within the textile sector-references on how we might produce and consume textiles in the coming decades.

The findings of the study are summarised in the table of futures scenarios (Table 1) and discussed further in this paper.

\subsection{Current State: Time Capsule on the Verge of 2020}

The news data show that on the verge of the 2020s, the textile industry and its sustainability issues were strongly present in the Finnish news media and intertwined with the wider discussions on topics such as consumer culture, climate and the environment. From the regulatory policy instrument perspective, current textile legislation largely emphasises consumer safety and health, placing less value on other aspects of sustainability. An interesting regulatory reform is on the horizon, as a European Union-wide textile waste directive is expected to come into effect in 2025, forcing textile waste separation, collection and recycling. The economic policy instruments under discussion vary from single taxation adjustments to a comprehensive tax reform that would systematically support sustainable choices in production and consumption and make unsustainable choices economically less profitable. Voluntary compensation payments have also been in the spotlight in Finland since spring 2019, when the Compensate Foundation announced its aim to offer an easy tool to offset carbon emissions at the cashier [42]. However, the scheme has since been under scrutiny, as there has been confusion concerning the nature of offsetting payments in light of Finnish fundraising laws [43]. Information as a policy instrument was mainly discussed in the data in the form of standards and eco-labelling, which in Finland have not been widely used, so far, in textiles, but are common in groceries, paper products and household cleaning products. Many businesses mention consumer influence and a 
growing public demand for responsible production and practices as the primary reason for more ambitious sustainability actions.

Good news from textile production describes new material innovations which are being actively developed in Finland with the aim of reducing the energy, water and/or pesticide demand connected to current textile raw material production. From the consumers' perspective, second-hand clothing stores and the shared use of textiles are gaining popularity and seem to tell a story of a growing environmental consciousness. At the same time, however, there is news of constantly growing textile consumption and a declining number of use times per garment. In 2019, sustainable consumerism was recognised as a growing trend in terms of values and attitudes, but not as a phenomenon that is visible in the statistics. Currently, the prevailing consensus among most producers and consumers is that the textile industry, or the production and consumption patterns in general, do not meet the standards of sustainability. The actions taken to turn this around have so far been inadequate considering the scale of the change needed.

\subsection{Preferable Futures Scenario: Ecological Reconstruction}

The preferable futures scenario was created from the news themes that appeared to be the most desired and most recommended in the expert evaluations. In this scenario, political direction is strong and consistent, making sure all actions are aimed at the shared sustainability goal. Legislation emphasises responsibility at the corporate level and in public procurement. Economic policy instruments take advantage of the alignment of taxes, and a consistent ecological tax reform has taken place. Environmental impacts are also considered when granting corporate subsidies. Eco-labels and standards as information policy means have become more common in textiles, following the progression in grocery items. Textile warranties and repair and maintenance services also function as messages of quality and lifecycle thinking. Consumer influence has been active and persistent, and sustainable consumption is a prevailing megatrend, not just a passion for a small consumer segment.

In the preferable futures scenario, the textile industry functions as a carbon-neutral circular economy. This has been achieved through a number of changes in textile production and consumption chains, such as new sustainably produced textile materials; material circulation; local, small-scale and high-quality production; shared use and other alternative ways to own and use textiles; high usage rate per garment; and lower water and energy consumption in the use-phase.

\subsection{Threatening Futures Scenario: Locked-in Systems}

The threatening futures scenario describes processes that appeared least favourable in the statements in the news articles and according to the views of the panellists. Without a clear and ambitious political direction, the textile industry's sustainability issues are hard, if not impossible, to tackle, and continue to worsen. Yet, drastic restrictions and sanctions also appeared undesirable in the data, and extreme economic policy instruments like personal emission or consumption quotas did not receive unreserved support among the panellists. In the news data, several arguments noted that taxation alone is often not very successful for influencing consumer behaviour. The same ineffectiveness has been noted at times in the case of voluntary influencing methods, such as information. Eco-labels and standards also pose a risk for a complex array of certifications and labels that are confusing rather than informative. An overall tightening of political control may cause resistance and rebellion among consumers, which makes changes particularly difficult to implement.

Some threats for future textile production include challenges to forest renewal, when growing wood pulp production for textile and other industries requires more natural resources. Textile production may also shift to new locations with looser emission restrictions, if the same rules are not applied in different countries and continents. In the worst-case scenarios, it has been estimated that the textile industry will be producing a quarter of world emissions by 2050 if no actions are taken to improve the industry. Unfavourable 
patterns of textile consumerism include growing numbers of purchases with fewer use times each and a continuing tendency to use price as the primary deciding factor, over quality and sustainability. A threatening textile future appears to be a locked-in system, where not enough leverage has been found to change the unsustainable patterns of today.

\subsection{Probable Futures Scenario: Circular Economy}

The notion that many of the processes in the preferable scenario also appear in the probable scenario is promising. The expert panellists' estimation was that the political direction would strengthen, with a legal demand for stronger corporate responsibility, and with public procurement responsibility as some of its likely forms. Changes in taxation were regarded as plausible means of using economic policy instruments. An environmental tax on products and services and/or a reform of the value added tax were seen as probable ways to make environmental impacts more visible in prices. The panellists also expected emission compensation payments to become more common and environmental impacts to factor more strongly in the allocation of corporate subsidies in the future. A wider use of textile eco-labels and standards were seen as likely forms of information policy instruments, but the challenge to summarise the diverse impacts of textile products into a single, informative label was also recognised. As for consumer influence, sustainable consumerism was expected to strengthen into somewhat of a megatrend, as unsustainable practices were seen simply as something we can no longer afford.

When looking at the big picture of textile production and consumption futures, novel materials and the aims for carbon neutrality and circular economy stand out in the data. The textile industry has a lot of unused potential to reuse and recycle its materials, and the economic profit from this can be expected to interest companies alongside the environmental benefits. The upcoming European Union-led textile waste directive that is expected to become binding in 2025 will likely support this cycle in pushing the development of textile sorting, collecting and recycling processes. High hopes are also placed on the development of new materials without the burden of water and pesticide-demanding cotton or energy-demanding polyester, for example. Wood-pulp-based materials, especially, are being developed in Finland, and the panellists expected them to grow in popularity. The production and consumption patterns of textiles show signs of diversifying, but in light of the data, the scale and significance of the change does not appear certain. Some statements in the news data and the literature suggest that the time of mass-produced-and massconsumed-fast fashion is inevitably coming to an end and will be replaced by conventions such as local micro-companies, craft-like production, second-hand, shared use, mending and quality over quantity; see, e.g., [13,44-46]. This shift did not appear as being definite in the expert panellists' evaluation; instead the current production and consumption patterns were expected to continue, hopefully with a more sustainable twist. Improvements in transportation and other technologies were expected to have an indirect effect on textiles too, making the environmental impact of their shipping, washing and other life-cycle activities lighter.

Out of the four steps to achieve a circular textile economy defined by The Ellen MacArthur Foundation [8] (pp. 22-25) and listed in Chapter 1.1., some, in light of this study, appear to be harder to actualise than others. The elimination of harmful substances, improved recycling and effective use of resources are, at least partly, technical solutions, which are constantly under development and do not necessarily need a drastic change in our behaviour to be fulfilled. Instead, the step "to break the disposable nature of clothes by transforming the ways they are designed, sold and used" is a more challenging one. It is also likely that most actions need a push from the policy makers. Niinimäki (2009) argues that the many socio-psychological powers that affect our consumption, such as clothes as identity building tools, are not likely to change at the necessary speed and scale the fashion industry needs to become more sustainable [47]. Rather, the change comes with taxation, standards and labels, separating fast and slow fashion production, and material 
and manufacturing innovations. The findings of this study agree with this notion, and are in accordance with the current publications $[5,10]$.

\subsection{Discussion of Policy Implications}

The aim of the three futures scenarios suggested in the study and described in the previous chapters was to draw attention to the different paths towards which the textile industry might be headed, depending, at least partly, on the use and choice of policy instruments. It appears likely that realising the most sustainable scenario requires a consistent and ambitious political direction. Societies collectively, and not only the textile sector, need sustainability to function as a guideline that determines the alignment of taxes, corporate subsidies and public procurement. The importance of the regulatory environment clearly stands out from the recent studies of Pineiro-Villaverde et al. (2020) and González-Sánchez et al. (2020) [5,10].

The unwanted threatening futures scenario is perhaps implausible in its all-embracing pessimism, but it is worth paying attention to the policy instrument pitfalls it points at: the change-paralysing public resistance in response to tightening political control; excessive trust on the rational consumer alone-or on taxation alone; the complicated and confusing eco-labels, instructions and directives. The probable textile futures scenario created here is hopeful. A sustainability-driven, stronger and more consistent use of policy instruments is expected in the future. The textile industry as a whole shows signs of diversifying in its use of raw materials, production practices and consumer behaviour, which may help break the patterns of the prevalent fast fashion formula.

\subsection{Limitations and Directions of Future Research}

The reliability and objectivity of this study were naturally of high priority, and using two distinct sets of data-news articles and expert panellists' evaluation-was expected to strengthen them. However, while the Finnish news media have a reputation for objectivity, truth and freedom of speech, it is worth remembering that a media text is not independent of the context of its production and from its reception and interpretation [48]. As for the second data set, a panel of five members is undeniably small and cannot be considered representative of experts in the whole textile sector.

Criticism directed at futures studies often focuses on the nature of future knowledge. There is some debate among the futurists, too, on questions such as how and what we can know about the future, or how to acquire valid and justified information about the future. One definition for future knowledge is given by Malaska (2013), who sees future knowledge as visionary knowledge, that combines factual knowledge with the researcher's outlook or intuition [49]. Visionary future knowledge is built on current objective knowledge and on interpretative knowledge about the past, making it more general and more subjective by nature [50] (pp. 99-100). It is fairly widely accepted that future knowledge is uncertain [31]. Futures studies typically aim to sketch different futures and ways to achieve or avoid them, and raise further questions about if and how we can consider some futures better or more desirable than others, and who can do so. For in-depth discussions on the ethics, morale and values in futures studies see, e.g., Bell (2003b) [51].

Futures studies commonly acknowledge several typical inconsistencies in our futureoriented thinking. We tend to overestimate the speed of change in the short term, and underestimate it in the long term; we are drawn to certainty and simplicity rather than uncertainty and complexity, and we consider preferred events to be more probable than unwanted events [40,52]. Taleb (2007) also writes about naïve empiricism and naïve generalization [34]. The former refers to our tendency to strengthen our own assumptions and views, and only notice opinions that are in line with them; the latter refers to our habit of expecting things to continue as they are, and making generalisations from one to many. In addition, futures studies often admit and agree to value relativism and cultural relativism to factor our ideas of preferred futures. This, as the majority of futures studies, has been executed in the Western countries, making Finland's position in the textile puzzle 
very different from that of a country with extensive textile manufacturing and exporting and/or limited resources for consuming and consumer choices. It is worth considering this basis and these future thinking assumptions, uncertainties and irrational tendencies when looking at the news articles, the panellists' evaluations as well as the conclusions drawn from them in this article. Futures are by no means black and white or simply good or bad, even if for the sake of planning and preparing we make scenarios that try to simplify complex entireties into tables and figures.

Futures studies do not search for the truth about the future but aim to have an impact on the decisions made in the present [53]. The objective of this study has been to raise awareness to textile-related directing methods, to gather previous research, current news media discussions and experts' views to better understand which tools are in use, which ones had unused potential and which ones are perhaps less suited to the textile industry and its sustainability challenges.

While exact suggestions for policy instrument implications were largely outside the scope of this study, some observations can be made. Firstly, policy makers should be familiar with the complex nature of the textile production and its multiple impacts. On a global scale, textile production is not irrelevant, but rather an integral sector when considering environmental issues, employment, economy or wellbeing, and thus needs to receive more attention from decision makers. Secondly, clear and actionable goals should be set for the textile production globally and locally. Would the priority be to diminish the environmental harm, obtain carbon neutrality and decrease the environmental pollution? Would the goal be to establish viable local textile manufacturing in Finland? Effective policy instruments require a systematic goal-oriented approach, and difficult choices will have to be made. Obviously, stronger corporate responsibility legislation (regulatory), environmental taxation of goods and services (economic) and eco-labelling of goods and services (information) are needed to support and drive the reforms. Thirdly, policy makers would need a futuristic mind-set and sensitivity to the weak and strong signals existing in the society. The responsible behaviour would need a shift of all actors from a product-oriented production and consumption model to a solution-oriented model, to integrate innovation and sustainability as a strategic choice for which new values need to be created $[54,55]$. Policy instruments could lay more emphasis on aspects such as ethical profile, reputation or degree of innovation of the industries [55]. To reach the sustainability goals, cooperation is essential, as well as a holistic change among all actors. Policy makers should create circumstances that enable partnerships across various industrial and societal sectors for value creation [10,56].

The consumer initiative towards sustainability should be supported and utilised, and continuous communication with consumers reinforced to increase knowledge [4], develop practices and make circular consumption more attractive, as studies show that environmental concerns, convenience and economic reasons are the dominant motivations in handling textiles [57] — and consumers should be seen as active drivers of change. We suggest, as Hüttel et al. (2020) [4], that education through personal experience and participation in circular product practices would increase sustainability, but at the same time it seems that economic benefits for consumers need to be ensured [57], e.g., a lower value added tax on repair services.

The all-encompassing digitalisation is important in the textile sector, and such practices should be supported. IC technologies provide tools for sustainability in manufacturing environments [54]. The year 2020 had its impacts on the way people live and consume, and the textile production chains had their share of these changes. Not only did online shopping increase but also digital clothing became a potential outfit choice for virtual meetings and events. Further, topics like the local security of supplies were suddenly relevant.

Further research is encouraged to obtain economic and political calculations and simulations, to provide specific information on which directing methods and their combinations in any situation would be most effective to tackle these challenges. Such assessments have 
already been made concerning the impacts of different directing methods on the carbon emissions of housing, traffic and food consumption in Finland [58].

This study showed that the futures studies methodology brings out novel aspects of textile production and consumption phenomena, which are, after all, quite traditional and socio-culturally determined. Future research with a larger group of expert panellists would provide a pragmatic emphasis to the research setting, and a wider and deeper understanding on which to base future directing methods. Further, this study concentrated on policy instruments but left the consumers unheeded. As the production and consumption phenomena are intertwined, it would also be important to study the consumers' perspective closely by applying futures studies.

\section{Conclusions}

While there is a certain amount of agreement on the need to make our societies more sustainable, there is still a lot of inconsistency in the objectives, political direction and actions when it comes to the execution. This was apparent in the data as well. Sustainable alternatives are not always economically profitable or easily available. The benefits of good practices are sometimes undone by harm from less favourable practices. Often there is no consensus on what the most favourable practice is. Policy instruments need updating to serve the needs of today and tomorrow better. A common goal is called for in the news data, a goal that is shared by producers and consumers, policy makers and citizens, different industries and different countries.

The first research question revealed different policy instruments that were, or could be, associated with textile production and consumption. Some instruments, like an environmental tax on products and services, repeatedly appeared in the news articles and enjoyed a fairly widespread support in the news discussions and expert panellists' views, while others, such as personal consumption quotas, appeared more as provocative dares.

Generally, the textile industry's sustainability outlooks, as studied in the second research question, appear to have a strong link to the circular economy, especially, and to carbon neutrality, to some extent. For the textile industry to operate under these principles, the news data and the expert panellists' evaluation suggest that a stronger political intervention is both needed and expected in the future. This ensures that sustainable textile choices are available, affordable and appealing to the consumer, and profitable for the producer. Whether it is consumer behaviour, technology, choice of materials, production location or all of the previous that we wish to change, all of these processes and evolutions are affected by the use of policy instruments which have the power to support what is desired. The strong message delivered by futures studies is that the future is not inevitable, and our values, rules and structures are neither dictated from outside nor set in stone but ours to create, choose and change as needed: we shape the future-and our images of the future shape us.

Author Contributions: Conceptualisation, L.V. and R.R.; methodology, L.V. and R.R.; software, L.V.; investigation, L.V.; resources, R.R.; formal analysis, L.V.; writing—original draft preparation, L.V. and R.R.; writing - review \& editing, L.V. and R.R.; visualisation, L.V.; supervision, R.R.; project administration, R.R. All authors have read and agreed to the published version of the manuscript.

Funding: This research received no external funding.

Institutional Review Board Statement: The study was conducted according to the guidelines of the University of Helsinki and the Finnish Advisory Board on Research Integrity 2012.

Informed Consent Statement: Informed consent was obtained from all subjects involved in the study.

Data Availability Statement: The data presented in this study are available on request from the corresponding author.

Acknowledgments: We want to thank Karin Bergbom, Outi Moilala, Marja Rissanen and the anonymous experts for their valuable contribution to this research. 
Conflicts of Interest: The authors declare no conflict of interest.

\section{References}

1. Niinimäki, K.; Peters, G.; Dahlbo, H.; Perry, P.; Rissanen, T.; Gwilt, A. The environmental price of fast fashion. Nat. Rev. Earth Environ. 2020, 1, 189-200. [CrossRef]

2. Gardetti, M.A.; Torres, A.L. Introduction. In Sustainability in Fashion and Textiles. Values, Design, Production and Consumption; Gardetti, M.A., Torres, A.L., Eds.; Greenleaf Publishing: Sheffield, UK, 2013; pp. 1-20. ISBN 978-1906093785.

3. Southerton, D.; Evans, D. Consumption policies within different theoretical frameworks. In Routledge Handbook on Consumption; Keller, M., Halkier, B., Wilska, T.-A., Truninger, M., Eds.; Routledge: London, UK, 2017; pp. 204-214. ISBN 9780367335854.

4. Hüttel, A.; Balderjahn, I.; Hoffmann, S. Welfare beyond consumption: The benefits of having less. Ecol. Econ. 2020, 176, 106719. [CrossRef]

5. Pineiro-Villaverde, G.; García-Álvarez, M.T. Sustainable consumption and production: Exploring the links with resources productivity in the EU-28. Sustainability 2020, 12, 8760. [CrossRef]

6. Nuutinen, A. Edelläkävijät. Hiljainen, Implisiittinen ja Eksplisiittinen Tieto Muodin Ennustamisessa. [Forerunners. Quiet, Implicit and Explicit Knowledge in Fashion Forecasting.]. Ph.D. Thesis, University of Art and Design, Helsinki, Finland, 2004.

7. Boström, M.; Micheletti, M. Introducing the sustainability challenge of textiles and clothing. J. Consum. Policy 2016, 39, 367-375. [CrossRef]

8. Ellen MacArthur Foundation. A New Textiles Economy: Redesigning Fashion's Future. 2017. Available online: https://www. ellenmacarthurfoundation.org/assets/downloads/A-New-Textiles-Economy_Full-Report_Updated_1-12-17.pdf (accessed on 30 October 2019).

9. Fletcher, K. Sustainable Fashion and Textiles. Design Journeys, 2nd ed.; Routledge: London, UK, $2014 ;$ ISBN 9780415644563.

10. González-Sánchez, R.; Settembre-Blundo, D.; Ferrari, A.M.; García-Muiña, F.E. Main dimensions in the building of the circular supply chain: A literature review. Sustainability 2020, 12, 2459. [CrossRef]

11. Quantis Home Page. Measuring Fashion: Insights from the Environmental Impact of the Global Apparel and Footwear Industries. Full Report and Methodological Considerations. 2018. Available online: https://quantis-intl.com/measuring-fashion-report (accessed on 1 November 2020).

12. United Nations Climate Change. UN Helps Fashion Industry Shift to Low Carbon. 2018. Available online: https://unfccc.int/ news/un-helps-fashion-industry-shift-to-low-carbon (accessed on 1 November 2020).

13. Heino, A.; Markkula, A.; Saario, M.; Sihvonen, H.; Ylimäki, L.; Kamaja, M.; Mikkonen, H.; Mäki, S. Hiilineutraali TekstiilialaTiekartta. [Carbon Neutral Textile Industry—A Road Map]; Final Report. 3.6.2020; Gaia Consulting and Finnish Textile \& Fashion: Helsinki, Finland, 2020; Available online: https:/ / www.stjm.fi/toiminta-alueemme/vastuullisuus/hiilineutraali-tekstiilialatiekartta/ (accessed on 12 July 2020).

14. Finnish Government Home Page. Programme of Prime Minister Sanna Marin's Government 2019. Available online: https:// valtioneuvosto.fi/en/marin/government-programme (accessed on 12 July 2020).

15. Ministry of Economic Affairs and Employment in Finland Home Page. Low-Carbon Roadmaps 2035. Available online: https://tem.fi/ en/low-carbon-roadmaps-2035 (accessed on 12 July 2020).

16. European Parliament News. What Is Carbon Neutrality and How Can It Be Achieved by 2050? Society. 3 October 2019. Available online: https://www.europarl.europa.eu/news/en/headlines/society/20190926STO62270/what-is-carbon-neutralityand-how-can-it-be-achieved-by-2050 (accessed on 12 July 2020).

17. Alhola, K.; Judl, J.; Norris, G.A.; Seppälä, J. Carbon Game Is On! Companies on the Move to be Carbon Neutral; Final Report 06/2015; Finnish Environmental Institute (SYKE): Helsinki, Finland, 2015; Available online: https://www.syke.fi/en-US/Research_ _Development/Research_and_development_projects/Projects/Carbon_neutrality (accessed on 12 July 2020).

18. ISO 14067-2018. Greenhouse Gases_Carbon Footprint of Products-Requirements and Guidelines for Quantification; International Organization for Standardization: Geneva, Switzerland, 2018.

19. Vedung, E. Policy instruments: Typologies and theories. In Carrots, Sticks \& Sermons. Policy Instruments E Their Evaluation; Bemelmans-Videc, M.-L., Rist, R.C., Vedung, E., Eds.; Transaction Publishers: New Brunswick, NJ, USA, 2010; pp. 21-58. ISBN 9780765805461

20. Seppälä, J.; Sahimaa, O.; Honkatukia, J.; Valve, H.; Antikainen, R.; Kautto, P.; Myllymaa, T.; Mäenpää, I.; Salmenperä, H.; Alhola, K.; et al. Kiertotalous Suomessa-Toimintaympäristö, Ohjauskeinot ja Mallinnetut Vaikutukset Vuoteen 2030 [Circular Economy in Finland-Operational Environment, Policy Instruments and Modelled Impacts by 2030]; Publications of the Government's Analysis, Assessment and Research Activities 2016; Prime Minister's Office: Helsinki, Finland, 2016. Available online: http://julkaisut.valtioneuvosto.fi/bitstream/ handle/10024/79586/Kiertotalous\%20Suomessa.pdf?sequence=1\&isAllowed=y (accessed on 21 November 2019).

21. Tax Administration Home Page. Value Added Tax Rates. Available online: https://www.vero.fi/en/businesses-and-corporations/ about-corporate-taxes/vat/rates-of-vat/ (accessed on 19 December 2020).

22. Finnish Customs Home Page. Customs Duties. Available online: https://tulli.fi/en/customs-duty-calculator?current=goods\& currency-id=1 (accessed on 19 December 2020). 
23. Nissinen, A.; Lähteenoja, S.; Alhola, K.; Antikainen, R.; Kaljonen, M.; Kautto, P.; Kuosmanen, J.; Lippo, A.; Salo, M. Tavoitteista Toiminnaksi-Kestävän Kulutuksen ja Tuotannon Visio ja Tärkeimmät Toimenpiteet [From Goals to Action-Vision and Most Important Measures for Sustainable Consumption and Production]; Finnish Environment Institute Report 31/2017; Finnish Environment Institute: Helsinki, Finland, 2017. Available online: https://helda.helsinki.fi/bitstream/handle/10138/228339/SYKEra_31_2017. pdf?sequence=1\&isAllowed=y (accessed on 21 November 2019).

24. Palpa Home Page. Beverage Packaging Recycling in Finland. Available online: https://www.palpa.fi/english/ (accessed on 19 December 2020).

25. Nicolaisen, K.-O.; Bugge, H.B. Ecolabelled Textiles in the Nordic Countries. English Summary to Nordic Working Paper; Nordic Working Papers 31.8.2018; Nordic Council of Ministers: Copenhagen, Denmark, 2018. [CrossRef]

26. Grankvist, G.; Dahlstrand, U.; Biel, A. The impact of consumer labeling on consumer preference: Negative vs. positive labels. J. Consum. Policy 2004, 27, 213-230. [CrossRef]

27. Huttunen, S.; Kivimaa, P.; Virkamäki, V. The need for policy coherence to trigger a transition to biogas production. Environ. Innov. Soc. Transit. 2014, 12, 14-30. [CrossRef]

28. Kivimaa, P.; Kern, F. Creative destruction or mere niche support? Innovation policy mixes for sustainability transitions. Res. Policy 2016, 45, 205-217. [CrossRef]

29. Dufva, M.; Laine, P.; Lähdemäki-Pekkinen, J.; Parkkonen, P.; Vataja, K. Tulevaisuusbarometri. Millaisena Suomalaiset Näkevät Tulevaisuuden? [Futures Barometer. How Finns Perceive the Future?]; Sitra Report 147; Sitra: Helsinki, Finland, 2019. Available online: https:/ / media.sitra.fi/2019/02/28132718/sitraselvityksiatulevaisuusbarometriverkkoon.pdf (accessed on 27 November 2019).

30. Tham, M. Futures of futures studies in fashion. In Routledge Handbook of Sustainability and Fashion; Fletcher, K., Tham, M., Eds.; Routledge: London, UK, 2015; pp. 283-292. ISBN 9781138232266.

31. Jarva, V. Skenaariodraama. Miten kirjoittaa vaikuttavia tulevaisuuskertomuksia? In Miten Tutkimme Tulevaisuuksia? [How to Study Futures?], 3rd ed.; Kuusi, O., Bergman, T., Salminen, H., Eds.; Tulevaisuuden Tutkimuksen Seura: Helsinki, Finland, 2013; pp. 154-178, ISBN 978-951-98852-3-0.

32. Tiberius, V. Path Dependence, Path Breaking, and Path Creation: A Theoretical Scaffolding for Futures Studies? J. Futures Stud. 2011, 15, 1-8. Available online: https://jfsdigital.org/articles-and-essays/2011-2/vol-15-no-4-june/articles/path-dependencepath-breaking-and-path-creation-a-theoretical-scaffolding-for-futures-studies/ (accessed on 12 July 2020).

33. Hiltunen, E. Weak Signals in Organizational Futures Learning; Acta Universitatis Oeconomicae Helsingiensis, A 365; Helsinki School of Economics: Helsinki, Finland, 2010.

34. Taleb, N.N. Musta Joutsen. Erittäin Epätodennäköisen Vaikutus. [The Black Swan. The Impact of the Highly Improbable]; Terra Cognita: Helsinki, Finland, 2007; ISBN 9789525697049.

35. Bell, W. Foundations of Future Studies. History, Purposes and Knowledge. Human Science for a New Era; Routledge: London, UK, 2003; Volume 1, ISBN 9780765805393.

36. Yle Home Page. Operating Principles. Available online: https://yle.fi/aihe/about-yle/operating-principles (accessed on 21 December 2020).

37. Sanoma Home Page. Corporate Responsibility. Available online: https://sanoma.com/corporate-responsibility/ (accessed on 21 December 2020).

38. Council for Mass Media Home Page. Basic Agreement. Available online: https://www.jsn.fi/en/Council_for_Mass_Media/ basic-agreement-of-the-council-for-mass-media/ (accessed on 21 December 2020).

39. United Nations Home Page. Transforming Our World: The 2030 Agenda for Sustainable Development. United Nations General Assembly 21 October 2015. A/RES/70/1. Available online: https://www.un.org/ga/search/view_doc.asp?symbol=A/RES/70 /1\&Lang=E (accessed on 9 January 2020).

40. Kuusi, O. Delfoi-menetelmä. In Miten Tutkimme Tulevaisuuksia? [How to Study Futures?], 3rd ed.; Kuusi, O., Bergman, T., Salminen, H., Eds.; Tulevaisuuden Tutkimuksen Seura: Helsinki, Finland, 2013; pp. 248-266, ISBN 978-951-98852-3-0.

41. Voros, J. Big History and anticipation: Using Big History as a framework for global foresight. In Handbook of Anticipation: Theoretical and Applied Aspects of the Use of Future in Decision Making; Poli, R., Ed.; Springer International: Cham, Switzerland, 2017. [CrossRef]

42. Compensate Home Page. Available online: https://compensate.com (accessed on 10 May 2020).

43. Yle News. Police Board Requests Investigation into Carbon-Offsetting Foundation. 2019. Available online: https://yle.fi/uutiset/ osasto/news/police_board_requests_investigation_into_carbon-offsetting_foundation/11140507 (accessed on 10 May 2020).

44. Thackara, J. A whole new cloth. Politics and the fashion system. In Routledge Handbook of Sustainability and Fashion; Fletcher, K., Tham, M., Eds.; Routledge: London, UK, 2015; pp. 43-51, ISBN 9781138232266.

45. Quinn, B. Fashion Futures; Merrell: London, UK, 2012; ISBN 9781845208080.

46. Anderson, C. Makers: The New Industrial Revolution; Crown Publishing: New York, NY, USA, 2012 ; ISBN 9781847940674.

47. Niinimäki, K. Consumer values and eco-fashion in the future. In Proceedings of the Conference Future of the Consumer Society, Tampere, Finland, 28-29 May 2009; Koskela, M., Vinnari, M., Eds.; Finland Futures Research Centre: Turku, Finland, 2009; pp. $125-134$.

48. Devereux, E. Understanding the Media, 3rd ed.; Sage: Los Angeles, CA, USA, 2014; ISBN 978-1446248805. 
49. Malaska, P. Tulevaisuustietoisuudesta ja tulevaisuudesta tietämisestä: Tulevaisuus mielenkiinnon kohteena. In Miten Tutkimme Tulevaisuuksia? [How to Study Futures?], 3rd ed.; Kuusi, O., Bergman, T., Salminen, H., Eds.; Tulevaisuuden tutkimuksen seura: Helsinki, Finland, 2013; pp. 14-22, ISBN 978-951-98852-3-0.

50. Kamppinen, M.; Malaska, P. Mahdolliset maailmat ja niistä tietäminen. In Tulevaisuudentutkimus. Perusteet ja Sovellukset [Futures Studies. Basics and Applications], 2nd ed.; Kamppinen, M., Kuusi, O., Söderlund, S., Eds.; Suomalaisen Kirjallisuuden Seura: Helsinki, Finland, 2003; pp. 55-115. ISBN 9789517466196.

51. Bell, W. Foundations of Future Studies. Values, Objectivity and the Good Society. Human Science for a New Era; Transaction Publishers: New Brunswick, NJ, USA, 2003; Volume 2, ISBN 9780765805669.

52. Soini-Salomaa, K. Käsi-ja Taideteollisuusalan Ammatillisia Tulevaisuuskuvia. [Future Professional Images in Craft and Design]. Ph.D. Thesis, University of Helsinki, Helsinki, Finland, 2013. Available online: http://urn.fi/URN:ISBN:978-952-10-9433-0 (accessed on 12 July 2020).

53. Mannermaa, M. Heikoista Signaaleista Vahva Tulevaisuus [From Weak Signals to Strong Futures]; Werner Söderström Osakeyhtiö: Helsinki, Finland, 2004; ISBN 9789510283721.

54. Garcia-Muiña, F.E.; González-Sánchez, R.; Ferrari, A.M.; Settembre-Blundo, D. The paradigms of industry 4.0 and circular economy as enabling drivers for the competitiveness of businesses and territories: The case of an Italian ceramic tiles manufacturing company. Soc. Sci. 2018, 7, 255. [CrossRef]

55. Settembre Blundo, D.; García-Muiña, F.E.; Pini, M.; Volpi, L.; Siligardi, C.; Ferrari, A.M. Sustainability as source of competitive advantages in mature sectors: The case of Ceramic District of Sassuolo (Italy). Smart Sustain. Built Environ. 2019, 8, 53-79. [CrossRef]

56. D'Adamo, I.; Falcone, P.M.; Morone, P.A. New Socio-economic indicator to measure the performance of bioeconomy sectors in Europe. Ecol. Econ. 2020, 176, 106724. [CrossRef]

57. Lehner, M.; Mont, O.; Mariani, G.; Mundaca, L. Circular economy in home textiles: Motivations of IKEA consumers in Sweden. Sustainability 2020, 12, 5030. [CrossRef]

58. Nissinen, A.; Heiskanen, E.; Perrels, A.; Berghäll, E.; Liesimaa, V.; Mattinen, M.K. Combination of policy instruments to decrease the climate impacts of housing, passenger transport and food in Finland. J. Clean. Prod. 2015, 107, 455-466. [CrossRef] 